\title{
Retinol induces morphological alterations and proliferative focus formation through free radical- mediated activation of multiple signaling pathways
}

\author{
Daniel Pens GELAIN*, Matheus Augusto de Bittencourt PASQUALI, Fernanda Freitas CAREGNATO, Mauro Antonio Alves \\ CASTRO, José Claudio Fonseca MOREIRA
}

Center for Oxidative Stress Research, Department of Biochemistry, Federal University of Rio Grande do Sul - Porto Alegre, RS, Brazil

\begin{abstract}
Aim: Toxicity of retinol (vitamin A) has been previously associated with apoptosis and/or cell malignant transformation. Thus, we investigated the pathways involved in the induction of proliferation, deformation and proliferative focus formation by retinol in cultured Sertoli cells of rats.

Methods: Sertoli cells were isolated from immature rats and cultured. The cells were subjected to a 24-h treatment with different concentrations of retinol. Parameters of oxidative stress and cytotoxicity were analyzed. The effects of the p38 inhibitor SB203580

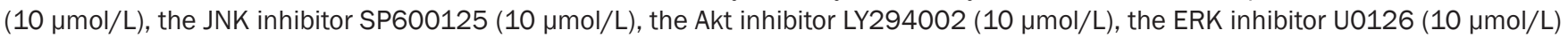

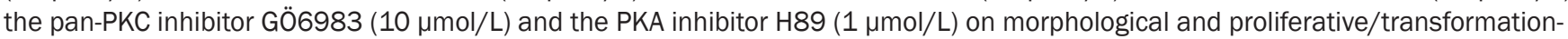
associated modifications were studied.

Results: Retinol (7 and $14 \mu \mathrm{mol} / \mathrm{L}$ ) significantly increases the reactive species production in Sertoli cells. Inhibition of p38, JNK, ERK1/2, Akt, and PKA suppressed retinol-induced $\left[{ }^{3} \mathrm{H}\right] \mathrm{dT}$ incorporation into the cells, while PKC inhibition had no effect. ERK1/2 and p38 inhibition also blocked retinol-induced proliferative focus formation in the cells, while Akt and JNK inhibition partially decreased focus formation. ERK1/2 and p38 inhibition hindered transformation-associated deformation in retinol-treated cells, while other treatments had no effect.

Conclusion: Our results suggest that activation of multiple kinases is responsible for morphological and proliferative changes associated to malignancy development in Sertoli cells by retinol at the concentrations higher than physiological level.
\end{abstract}

Keywords: retinol; vitamin toxicity; Sertoli cell; oxidative stress; cell deformation; p38; JNK; Akt; ERK; PKC; PKA

Acta Pharmacologica Sinica (2012) 33: 558-567; doi: 10.1038/aps.2011.202; published online 19 Mar 2012

\section{Introduction}

Vitamin A (retinol) affects several biological processes through diverse mechanisms. Classically, it was believed that most actions of retinol were mediated only by different isomers of retinoic acid (RA), which is obtained from retinol enzymatic dehydrogenation ${ }^{[1]}$. RA modulates the transcription of several genes associated to cell cycle regulation through the action of the so-called retinoid receptors, which belong to the superfamily of steroid/thyroid receptors ${ }^{[2]}$. Gene transcription regulated by retinoid receptors influences cell death/survival, differentiation and growth, and is believed to exert an important role in neural development ${ }^{[3]}$.

Besides this genomic action, there has been some recent

\footnotetext{
* To whom correspondence should be addressed.

E-mail dgelain@yahoo.com.br

Received 2011-11-07 Accepted 2011-12-19
}

attention to a potential role in redox modulation of oxidative balance at cellular and systemic levels by retinol ${ }^{[4]}$. Based on epidemiologic studies, retinol was suggested to be an important dietary antioxidant, preventing pathologies associated to oxidative stress such as cancer, atherosclerosis, neurodegenerative diseases and other age-related conditions ${ }^{[5]}$. On the other hand, extensive trials of retinol supplementation resulted in increased incidence of lung cancer and cardiovascular diseases ${ }^{[6,7]}$, and more recent works on the redox properties of retinol and other retinoids revealed a pro-oxidant action at specific concentrations and experimental conditions ${ }^{[8-10]}$. Besides, retinol and RA have been reported to regulate cellular processes not related to retinoid receptor-mediated gene transcription, in which has been denominated a "non-genomic" action $^{[11,12]}$. These actions were observed to influence synaptic transmission, catecholamine production and also cell cycle regulation through mitogen-activated protein kinase (MAPK), 
Akt and Protein Kinase C (PKC) activation ${ }^{[11,13-15]}$. Since oxidative stress and protein kinase activation have been extensively associated with cancer induction, it has been speculated that non-genomic actions of vitamin A may account for many of these pro-neoplastic effects.

We have previously observed that retinol is able to enhance reactive species production and induce extensive oxidative damage in Sertoli cells, a physiological target of retinol ${ }^{[16-21]}$. In these cells, retinol and RA are endocrine factors that regulate diverse reproductive-related functions in a constitutive fashion. Although Sertoli cells are "professional" vitamin A targets, retinol is also able to induce cell cycle impairment and DNA damage via reactive species production at concentrations slightly above the reported physiological limit ${ }^{[19-21]}$. In this regard, primary Sertoli cell cultures constitute an excellent model to study the mechanisms and effects of vitamin A supplementation at cellular level.

Considering that the role of retinol in diet supplementations or in new therapies to treat or prevent malignant processes is still a matter of debate, here we investigated the effects of retinol on morphological parameters associated to pre-neoplasic morphological transformation and mitosis in Sertoli cell cultures, aiming to determine the role of the MAPKs ERK1/2, p38 and Jun-activated kinase (JNK), the protein kinase Akt, the cAMP-activated Protein Kinase (PKA) and PKC.

\section{Material and methods}

\section{Chemicals and animals}

Pregnant Wistar rats were housed individually in Plexiglas cages. Litters were restricted to eight pups each. Animals were maintained on a 12-h light/dark cycle at a constant temperature of $23^{\circ} \mathrm{C}$, with free access to commercial food and water. Male immature rats (15 days old) were killed by cervical dislocation. All experiments were conducted in accordance with the National Institute of Health Guide for the Care and Use of Laboratory Animals (NIH publication number 80-23 revised, 1996). Our research protocol was approved by the Ethical Committee for animal experimentation of the Federal University of Rio Grande do Sul. All-trans retinol alcohol, epinephrine, thiobarbituric acid, dinitrophenylhydrazine, Trolox, Tween-20, and $\beta$-mercaptoethanol were purchased from Sigma Chemical Co (St Louis, MO, USA). U0126 was from Promega Corporation (Madison, WI, USA), GÖ6983 and SB203580 were from Merck Biosciences (Darmstadt, Germany) and H89 was from Biomol Research Laboratories (Plymouth Meeting, PA, USA). Other kinase inhibitors were kind gifts from Professor Peter DUNKLEY (University of Newcastle, NSW, Australia). Rabbit polyclonal antibodies against phosphorylated forms of p38, JNK, ERK1/2 and Akt were obtained from Santa Cruz Biotechnology Inc (Santa Cruz, CA, USA), and monoclonal anti- $\beta$-actin was from Sigma. West Pico chemiluminescent kit was obtained from Pierce (Rockford, IL, USA). Concentrated stocks of solutions were prepared immediately before experiments by diluting retinol into ethanol and determining final stock concentration by UV absorption; solution was kept protected from light and temperature during all procedures. Appropriate solvent controls were performed for each condition. Treatments were initiated by adding concentrated solutions to reach final concentrations in the well. The final ethanol concentration did not exceed $0.2 \%$ in any experiment. Electrophoresis reagents and equipment were from BioRad (Hercules, CA, USA). Tissue culture reagents were from Gibco (Invitrogen Corporation, Carlsbad, CA, USA) and were of tissue culture grade.

\section{Isolation and culture of Sertoli cells and assays}

Sertoli cells were isolated as previously described ${ }^{[18]}$. Briefly, testes of 15-day-old rats were removed, decapsulated and digested enzymatically with trypsin and deoxyribonuclease for $30 \mathrm{~min}$ at $37^{\circ} \mathrm{C}$, and centrifuged at $750 \times g$ for $5 \mathrm{~min}$. The pellet was mixed with soybean trypsin inhibitor, then centrifuged and incubated with collagenase and hyaluronidase for $30 \mathrm{~min}$ at $37^{\circ} \mathrm{C}$. After incubation, this fraction was centrifuged (10 $\mathrm{min}$ at $40 \times \mathrm{g}$ ). The pellet was taken to isolate Sertoli cells and supernatant was discarded. After counting, Sertoli cells were plated in multiwell plates $\left(3 \times 10^{5}\right.$ cells $\left./ \mathrm{cm}^{2}\right)$ in Medium 199 pH 7.4 1\% FBS, and maintained in humidified 5\% $\mathrm{CO}_{2}$ atmosphere at $37^{\circ} \mathrm{C}$ for $24 \mathrm{~h}$ for attachment. The medium was then changed to serum-free medium and cells were maintained for more $24 \mathrm{~h}$. Medium was then replaced by fresh medium containing treatments and cells were incubated for more $24 \mathrm{~h}$. Morphology was examined at the end of the $24 \mathrm{~h}$ treatments.

\section{Measurement of mitochondrial superoxide production}

Mitochondrial superoxide production was assessed as previously described $^{[18]}$. To isolate submitochondrial particles (SMP) from Sertoli cell cultures, cells were homogenized in an isolation buffer $(230 \mathrm{mmol} / \mathrm{L}$ mannitol, $70 \mathrm{mmol} / \mathrm{L}$ sucrose, 10 mmol/L Tris-HCl, 1 mmol/L EDTA, pH 7.4). Homogenates were centrifuged $(750 \times g, 10 \mathrm{~min})$ to eliminate nuclei and cell debris and the pellet was washed to enrich supernatant; the supernatant was then centrifuged at $7000 \times g$ for $10 \mathrm{~min}$. The pellet was washed and resuspended in the same buffer, and then SMP were obtained by freezing and thawing (three times) this fraction. The resulting SMP are washed twice with buffer consisting of $140 \mathrm{mmol} / \mathrm{L} \mathrm{KCl}$ and $20 \mathrm{mmol} / \mathrm{L}$ Tris- $\mathrm{HCl}(\mathrm{pH}$ 7.4) and resuspended in the same medium for determination of superoxide production, which was assessed by mixing SMP solution (0.3-0.1 $\mathrm{mg}$ protein/ $\mathrm{ml}$ ) to a reaction medium consisting of $230 \mathrm{mmol} / \mathrm{L}$ mannitol, $70 \mathrm{mmol} / \mathrm{L}$ sucrose, $20 \mathrm{mmol} / \mathrm{L}$ Tris- $\mathrm{HCl}$ (pH 7.4), plus $0.1 \mathrm{mmol} / \mathrm{L}$ catalase and $1 \mathrm{mmol} / \mathrm{L}$ epinephrine. Succinate $(7 \mathrm{mmol} / \mathrm{L})$ was used as substrate, and the superoxide-dependent oxidation of epinephrine to adrenochrome at $37^{\circ} \mathrm{C}$ (Extinction molar coefficient at $480 \mathrm{~nm}$ and $\mathrm{nm}$ and $4020 \mathrm{mmol} \cdot \mathrm{L}^{-1} \cdot \mathrm{cm}^{-1}$ ) was followed by spectrophotometry detection. SOD was used at $0.1-0.3 \mathrm{mmol} / \mathrm{L}$ final concentration to assess assay specificity.

\section{Thiobarbituric acid reactive species (TBARS)}

As an index of lipid peroxidation, we quantified the formation of TBARS formed in an acid-heating reaction of cell 
lipid extracts with thiobarbituric acid ${ }^{[22]}$. Briefly, the cell homogenates were mixed with $0.6 \mathrm{~mL}$ of $10 \%$ trichloroacetic acid (TCA) and $0.5 \mathrm{~mL}$ of $0.67 \%$ thiobarbituric acid, and then heated in a boiling water bath for $25 \mathrm{~min}$. TBARS were determined by the absorbance in a spectrophotometer at $532 \mathrm{~nm}$. Results were normalized against the content of cell protein and expressed as TBARS/mg of protein.

\section{Measurement of protein carbonyls}

The oxidative damage to proteins was measured by the quantification of carbonyl groups based on the reaction with dinitrophenylhidrazine $(\mathrm{DNPH})^{[23]}$. Briefly, proteins were precipitated by the addition of 20\% TCA, redissolved in DNPH and the absorbance was read in a spectrophotometer at $370 \mathrm{~nm}$. Results were expressed as nmol carbonyl/mg of protein.

\section{Proliferation focus assessment}

Cell focus assay was carried as previously described ${ }^{[18]}$. Briefly, Sertoli cells were treated during $24 \mathrm{~h}$ with retinol in the presence or absence of different protein kinase inhibitors. The incubation medium was then replaced by Medium 199 (pH 7.4) supplemented with 10\% FBS in all groups. Cells were maintained in humidified $5 \% \mathrm{CO}_{2}$ atmosphere at $37^{\circ} \mathrm{C}$ for $14 \mathrm{~d}$, with medium replacement every $3 \mathrm{~d}$. Morphology was examined during this period and cell foci were scored at the end of the experiment under a light microscope (Nikon Eclipse TE 300). Photomicrography images were captured at the end of the $24 \mathrm{~h}$-period of incubation with retinol and also at the end of the $14 \mathrm{~d}$-period of proliferative focus induction.

\section{Cell proliferation assay}

As an index of cell proliferation we used the incorporation of [methyl- $\left.{ }^{3} \mathrm{H}\right]$ thymidine $\left(\left[{ }^{3} \mathrm{H}\right] \mathrm{dT}\right)$. Briefly, after the first $24 \mathrm{~h}$ of culture in Medium 199 at 1\% FSB, the medium was replaced for serum-free Medium 199 supplemented with $2.5 \mu \mathrm{Ci} / \mathrm{mL}$ of $\left.{ }^{3} \mathrm{H}\right] \mathrm{dT}$ (248 GBq/mmoL; Amersham International, Amersham, UK). After $24 \mathrm{~h}$, the medium was replaced by the same medium containing retinol and different protein kinase inhibitors, and cells were incubated for more $24 \mathrm{~h}$. Cells were then washed, harvested, suspended in nucleus isolation buffer (50 mmol/ $\mathrm{L} \mathrm{NaPO}_{4}, 2 \mathrm{~mol} / \mathrm{L} \mathrm{NaCl}, \mathrm{pH} 7.4$ ) and centrifuged (5 min, $14000 \times g$ ) to extract nuclear DNA. An aliquot was used to determine $\left[{ }^{3} \mathrm{H}\right] \mathrm{dT}$ incorporation into DNA in a Packard TriCarb Model 3320 scintillation counter, and another aliquot was utilized for protein quantification.

\section{Deformation coefficient $D$ measurement}

The morphological relation between spreading and confluent cells was measured to assess modifications in cell plasticity. The increase in the difference between spread and confluent cells implies an increase of coefficient $D^{[24]}$. Morphometrical measurements were obtained by analysis of the scanned phase-contrast photomicrographs of cells plated as dispersed and confluent densities. At least 35 cells from each experimental group in three independent experiments were measured to evaluate shape parameters of each cell. Data are reported as mean $\pm S E M$, with the level of significance set at $P<0.05$.

\section{Immunoblot}

To perform immunoblot experiments, Sertoli cell cultures were lysed in Laemmli-sample buffer $(62.5 \mathrm{mmol} / \mathrm{L}$ Tris- $\mathrm{HCl}$, $\mathrm{pH} 6.8,1 \%(w / v)$ SDS, $10 \%(v / v)$ glycerol) and equal amounts of cell proteins (approximately $35 \mu \mathrm{g} /$ lane) were fractionated by SDS-polyacrylamide gel electrophoresis (PAGE) and electroblotted onto polyvinyledilene difluoride (PVDF) membranes. Protein loading and electrobloting efficiency were verified by Ponceau $S$ staining, and the membrane was then blocked in Tween-Tris buffered saline (TTBS; $100 \mathrm{mmol} / \mathrm{L}$ Tris- $\mathrm{HCl}, \mathrm{pH}$ 7.5, containing $0.9 \% \mathrm{NaCl}$ and $0.1 \%$ Tween-20) containing 5\% albumin and incubated overnight with the primary antibody to be tested. The membrane was washed in TTBS and incubated with horseradish peroxidase coupled anti-IgG antibody, washed again and the immunoreactivity was detected by enhanced chemiluminescence. Densitometric analysis of the films was performed with GraphPad Software Inc; San Diego, CA, USA. Blots were developed to be linear in the range used for densitometry.

\section{Data normalization and statistics}

Data were normalized by protein content, which was measured by the Lowry method. Normalized data was analyzed with GraphPad software by one-way ANOVA with Duncan's post-hoc test. Differences were considered significant when $P<0.05$.

\section{Results}

Previously, we reported that retinol induced oxidative stress at $7 \mu \mathrm{mol} / \mathrm{L}$ during $24 \mathrm{~h}$ of incubation ${ }^{[17]}$. To confirm this observation, here we incubated Sertoli cells with retinol for $24 \mathrm{~h}$ to establish the concentrations at which retinol was able to induce oxidative stress. Cytosolic concentrations of retinol at physiological conditions have been reported to range between 0.2 to $5 \mu \mathrm{mol} / \mathrm{L}^{[25]}$; for this reason, we incubated Sertoli cells with concentrations ranging from physiological (2 and 5 $\mu \mathrm{mol} / \mathrm{L}$ ) to elevated levels (7 and $14 \mu \mathrm{mol} / \mathrm{L}$ ). As previously observed $^{[26]}$, mitochondrial superoxide production (Figure 1A), carbonyl levels (Figure 1B) and lipid peroxidation (Figure 1C) were significantly increased by retinol at $7 \mu \mathrm{mol} / \mathrm{L}$; retinol at $2 \mu \mathrm{mol} / \mathrm{L}$ or $5 \mu \mathrm{mol} / \mathrm{L}$ had no effect on these parameters. In previous reports, we also observed that retinol enhances intracellular free radical production at 7 and $14 \mu \mathrm{mol} / \mathrm{L}$, but the concentration of $14 \mu \mathrm{mol} / \mathrm{L}$ also led to extensive cell death after $24 \mathrm{~h}$ of incubation ${ }^{[27]}$. Altogether, these results confirmed that retinol increases reactive species production at $7 \mu \mathrm{mol} / \mathrm{L}$ and $14 \mu \mathrm{mol} / \mathrm{L}$, and increasing concentrations of retinol may induce cytotoxic effects probably due to uncontrolled oxidative damage to cells.

Retinol did not cause any detectable morphological changes in cell monolayers at $2 \mu \mathrm{mol} / \mathrm{L}$ and $5 \mu \mathrm{mol} / \mathrm{L}$ (Figure 2). On the other hand, retinol $7 \mu \mathrm{mol} / \mathrm{L}$ induced visible morphologic modifications in the cell. At the concentration of $14 \mu \mathrm{mol} / \mathrm{L}$ 
A

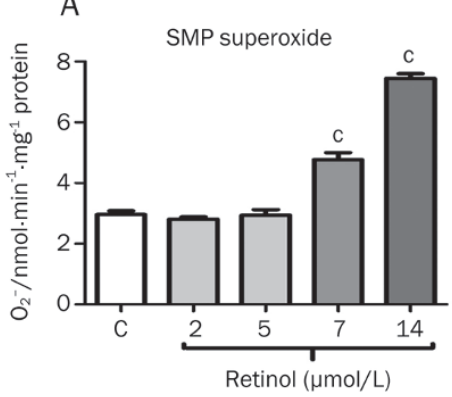

B

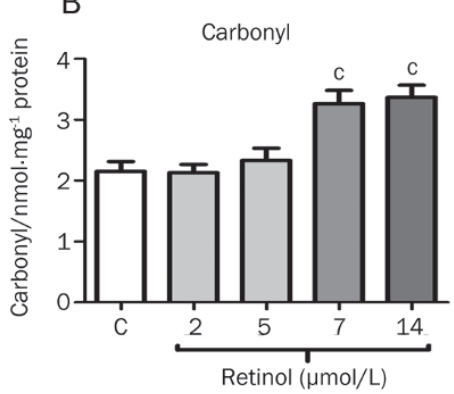

C

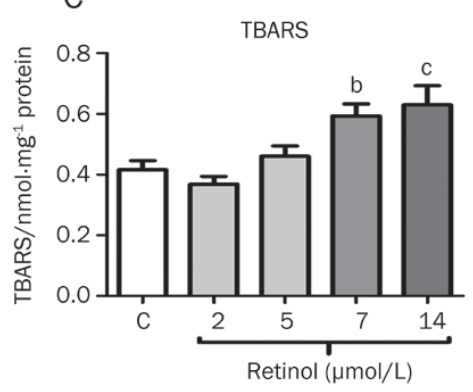

Figure 1. Sertoli cells were treated with retinol for $24 \mathrm{~h}$ and different parameters related to oxidative stress and cell damage were assessed. (A) Superoxide production by submitochondrial particles isolated from retinol-treated cells was measured, and oxidative damage was assessed by quantification of $(B)$ carbonyl and $(C)$ TBARS levels. $C=$ control in all graphs. Bars represent mean $\pm S E M$ from three independent experiments (triplicate); data were analyzed by one-way ANOVA with Duncan's post hoc test. ${ }^{\mathrm{b}} P<0.05,{ }^{\mathrm{C}} P<0.01$ vs control.
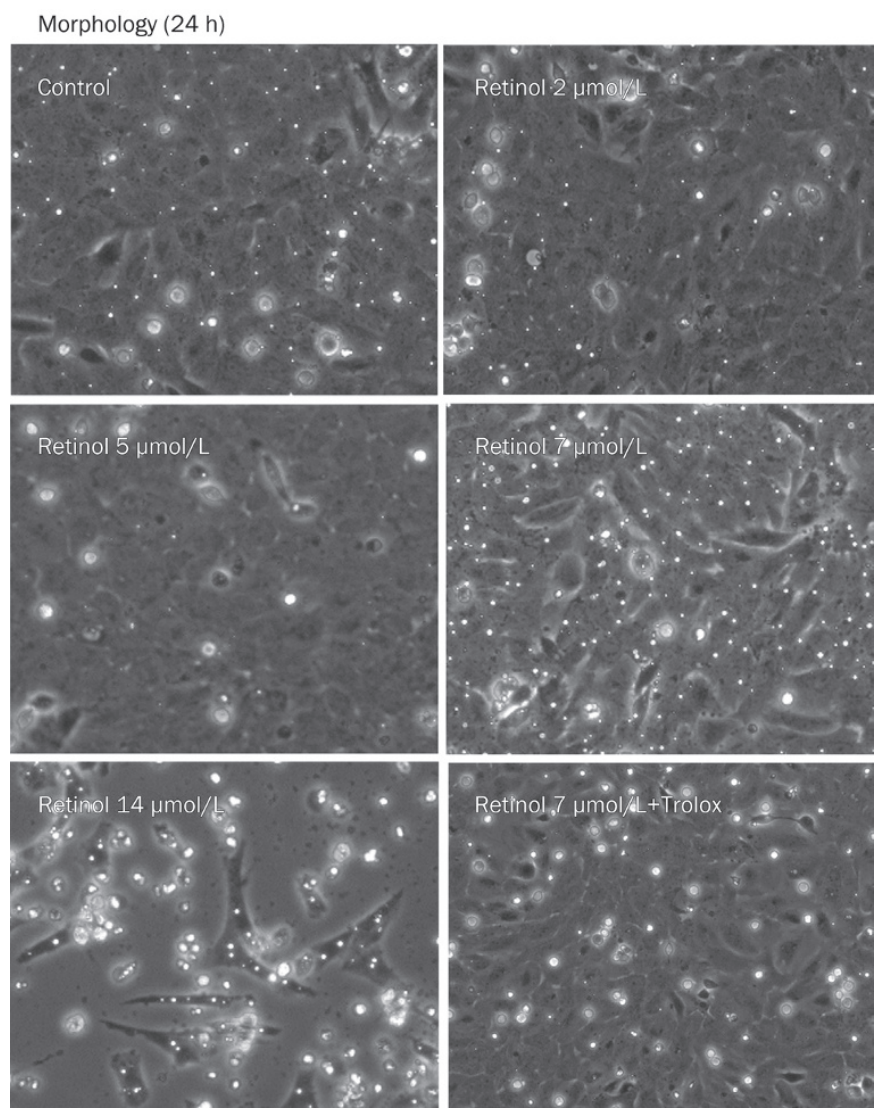

Figure 2. Cell morphology was examined by phase-contrast microscopy (Nikon Eclipse TE 300, ×100). Sertoli cells were treated with retinol at $2,5,7$, and $14 \mu \mathrm{mol} / \mathrm{L}$ for $24 \mathrm{~h}$. Retinol $7 \mu \mathrm{mol} / \mathrm{L}$ induced mild body cell shrinkage and retinol $14 \mu \mathrm{mol} / \mathrm{L}$ caused extensive cell detachment. Trolox $(100 \mu \mathrm{mol} / \mathrm{L})$ inhibited the effect of retinol $7 \mu \mathrm{mol} / \mathrm{L}$.

most cells were detached. Co-incubation with the antioxidant Trolox $(0.1 \mathrm{mmol} / \mathrm{L})$ prevented the changes in morphology induced by retinol, indicating the involvement of oxidative stress in this effect. Based on these results and on the results presented at Figure 1 we used the concentration of $7 \mu \mathrm{mol} / \mathrm{L}$ to test the pro-oxidant effects of retinol on morphological and proliferation parameters of Sertoli cells throughout this work.

In previous works, we demonstrated that retinol led to the activation of different signaling pathways in an oxidantdependent fashion, and that the antioxidant Trolox inhibited this effect ${ }^{[15,18]}$. Here, we wanted to establish the possible involvement of different signaling pathways in the induction of morphological and proliferative changes in Sertoli cells by analyzing parameters related to pre-neoplasic transformation. With this aim, we performed assays using pharmacological inhibitors of different MAPKs involved in cell cycle activation and transformation, such as p38, ERK1/2, and JNK, as well as inhibitors of PKA, PKC, and Akt. Sertoli cells were incubated with retinol and protein kinase inhibitors for $24 \mathrm{~h}$, and the cell morphology was examined by phase-contrast microscopy (Figure 3A).

We observed here that the JNK inhibitor SP600125 (10 $\mu \mathrm{mol} / \mathrm{L}$ ) blocked the morphological alterations induced by retinol (Figure 3A). The other protein kinase inhibitors had no effect or caused new patterns of morphology modification in retinol-treated cells, such as observed for the p38 inhibitor SB203580 $(10 \mu \mathrm{mol} / \mathrm{L})$ and the Akt inhibitor LY294002 (10 $\mu \mathrm{mol} / \mathrm{L}$ ). To better understand how these morphological modifications were associated to malignant deformation, we calculated the deformation coefficient $D$ (Figure 3B), a morphological relationship among spreading and confluent cells, related to cell malignancy, invasiveness and contact inhibition applied to cancer cell lines ${ }^{[24]}$. The coefficient $D$ for cells treated with retinol for $24 \mathrm{~h}(D=2.812 \pm 0.229)$ was significantly lower than in control cells $(D=5.258 \pm 0.538)$, indicating loss of substrate adhesion and contact inhibition ${ }^{[24]}$. Besides Trolox, the p38 inhibitor SB203580 and the ERK1/2 inhibitor U0126 $(10 \mu \mathrm{mol} / \mathrm{L})$ also inhibited this effect, while other protein kinase inhibitors did not. Cells co-treated with retinol and the PKA inhibitor H89 presented a negative value for the coefficient $D$, which is probably related to a loss of cell integrity resulting in cell detachment observed at later time periods (data not shown). These results suggest that p38 and ERK1/2 are involved in the activation of signaling pathways leading to morphological changes related to loss of contact inhibition and modulation of cell adhesion. 


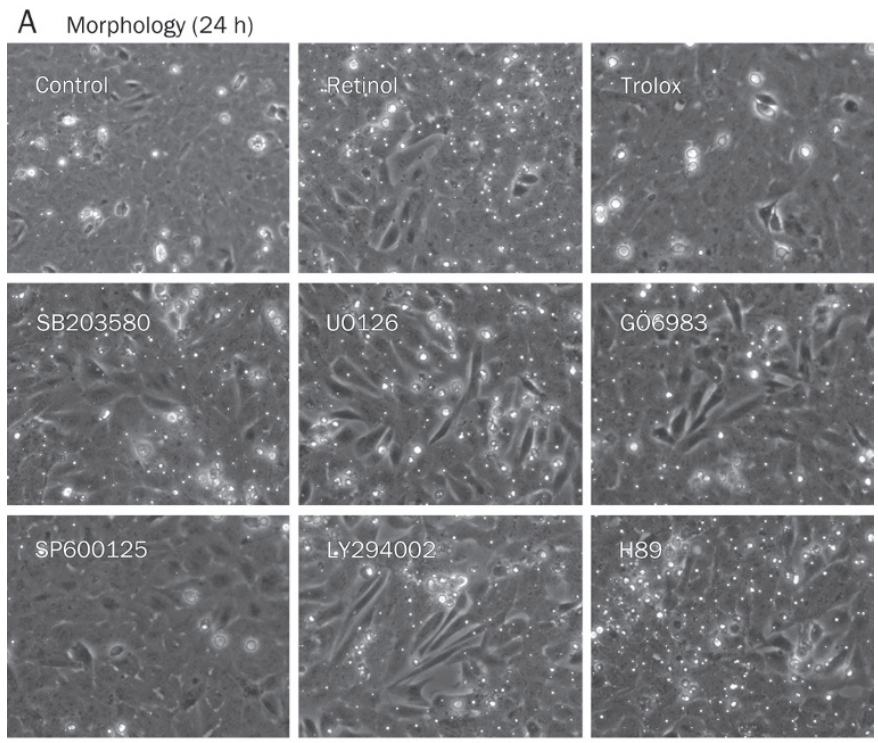

B Cell shape deformation $(24 \mathrm{~h})$

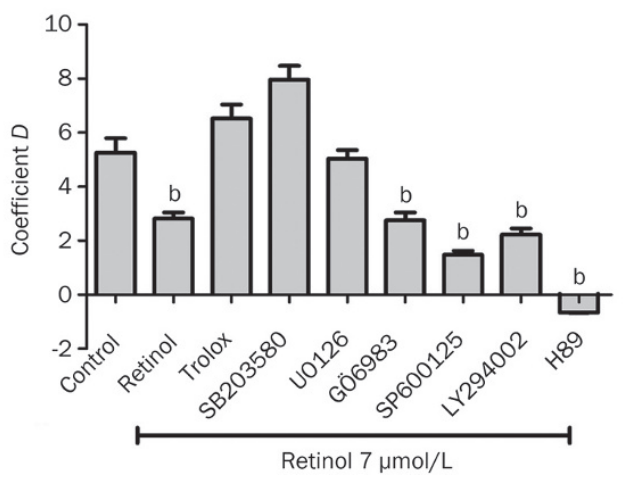

Figure 3. Effect of different protein kinase inhibitors on cell morphology modification by retinol. (A) Sertoli cells were treated with retinol $7 \mu \mathrm{mol} / \mathrm{L}$ in the presence or absence of the antioxidant Trolox $(100 \mu \mathrm{mol} / \mathrm{L})$, the p38

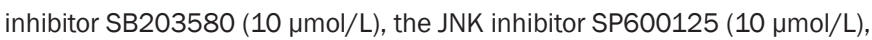
the Akt inhibitor LY294002 (10 $\mu \mathrm{mol} / \mathrm{L})$, the ERK inhibitor U0126 (10 $\mu \mathrm{mol} / \mathrm{L})$ the pan-PKC inhibitor GÖ6983 $(10 \mu \mathrm{mol} / \mathrm{L})$ and the PKA inhibitor $\mathrm{H} 89$ ( $1 \mu \mathrm{mol} / \mathrm{L})$ for $24 \mathrm{~h}$, and the cell morphology was examined by phasecontrast microscopy (Nikon Eclipse TE 300, ×100). (B) Cell deformation after $24 \mathrm{~h}$ was also analyzed by calculation of the coefficient $D$, an index of cell transformation-related deformation, obtained by morphometrical measurement of scanned phase-contrast photomicrographs of cells plated at dispersed and confluent densities. Bars represent mean $\pm S E M$ from 22 individual cells analyzed per each group; data were analyzed by one-way ANOVA with Duncan's post hoc test. ${ }^{\mathrm{b}} \mathrm{P}<0.05$ in relation to control.

In previous works, we found that Sertoli cell cultures treated with retinol for $24 \mathrm{~h}$ developed spots of proliferative focus when subjected to a 14 d-treatment with $10 \%$ Fetal Bovine Serum (FBS)-supplemented culture medium ${ }^{[18,20]}$. Here, we studied the inhibition of different kinases on this effect. With this aim, Sertoli cells were incubated for $24 \mathrm{~h}$ with retinol in the presence or absence of the different protein kinase inhibitors; after this treatment, the medium in all groups was replaced for fresh 10\% FBS medium (without retinol and protein kinase inhibitors), and cells were cultured in these conditions for 14 $\mathrm{d}$ with medium replacement every $3 \mathrm{~d}$. In cells treated with retinol we observed a significant increase in proliferative focus formation, which was blocked by Trolox (Figure 4 and 5A). The ERK1/2 inhibitor U0126 also blocked retinol-induced proliferative focus formation, and p38 inhibition significantly decreased the number of proliferative focus in the plate well. PKC, Akt, and JNK inhibition had no effect on retinol-induced proliferative focus formation. Cells treated with retinol plus the PKA inhibitor H89 (1 $\mu \mathrm{mol} / \mathrm{L})$ for 24 detached from culture dishes within 1 week of $10 \%$ FBS-medium incubation.

Previously, we observed that retinol induced an increase in $\left[{ }^{3} \mathrm{H}\right] \mathrm{dT}$ incorporation that was associated to activation of cell division $^{[18]}$. Here, we investigated the effect of the different protein kinases on this parameter. As previously observed, Sertoli cells incubated with retinol for $24 \mathrm{~h}$ had increased $\left[{ }^{3} \mathrm{H}\right] \mathrm{dT}$ (Figure 5B), and this effect was prevented by the antioxidant Trolox. The p38 inhibitor SB203580, the JNK inhibitor SP600125, the Akt inhibitor LY294002 and the ERK inhibitor U0126 decreased $\left[{ }^{3} \mathrm{H}\right] \mathrm{dT}$ incorporation to control levels when co-incubated with retinol. The pan-PKC inhibitor GÖ6983 $(10 \mu \mathrm{mol} / \mathrm{L})$ did not affect $\left[{ }^{3} \mathrm{H}\right] \mathrm{dT}$ incorporation, while the PKA inhibitor $\mathrm{H} 89$ decreased $\left[{ }^{3} \mathrm{H}\right] \mathrm{dT}$ incorporation in retinoltreated cells.

Altogether, our results suggest that the protein kinases p38, Akt, JNK, and ERK1/2 are associated to morphological changes, proliferative focus formation and activation of cell division induced by pro-oxidant concentrations of retinol. We then evaluated the activation states of these protein kinases by the immunodetection of their phosphorylated (i.e., active) isoforms by western blot (Figure 6). We observed an increase in the phosphorylation of p38, Akt, JNK, and ERK1/2 within $60 \mathrm{~min}$ of incubation with retinol $7 \mu \mathrm{mol} / \mathrm{L}$ (Figure 6A); phosphorylation levels of all kinases peaked around 15-30 min. We evaluated the effect of Trolox on the phosphorylation state of each protein kinase in Sertoli cells treated with retinol by $15 \mathrm{~min}$, and compared with the effect of each specific protein kinase inhibitor. Trolox was able to completely or partially inhibit the effect of retinol on the phosphorylation of all kinases; besides, our results confirm that the protein kinase inhibitors SB203580, LY294002, SP600125, and U0126 were all effective in inhibiting, respectively, p38, Akt, JNK, and ERK1/2 phosphorylation.

\section{Discussion}

Retinol and retinoic acid are widely recognized as potent morphogens ${ }^{[1]}$. Retinoids regulate gene transcription through nuclear receptors belonging to the superfamily of steroid/ thyroid/vitamin D-related hormone receptors known as retinoid receptors ${ }^{[3]}$. Such nuclear action is considered a key point in brain development and establishment of morphological patterns during embryonic and fetal development ${ }^{[2]}$. The observation of antioxidant properties of vitamin A in vitro and in vivo also led to the hypothesis that retinol and derivatives could act in cancer prevention/treatment, due to combined 

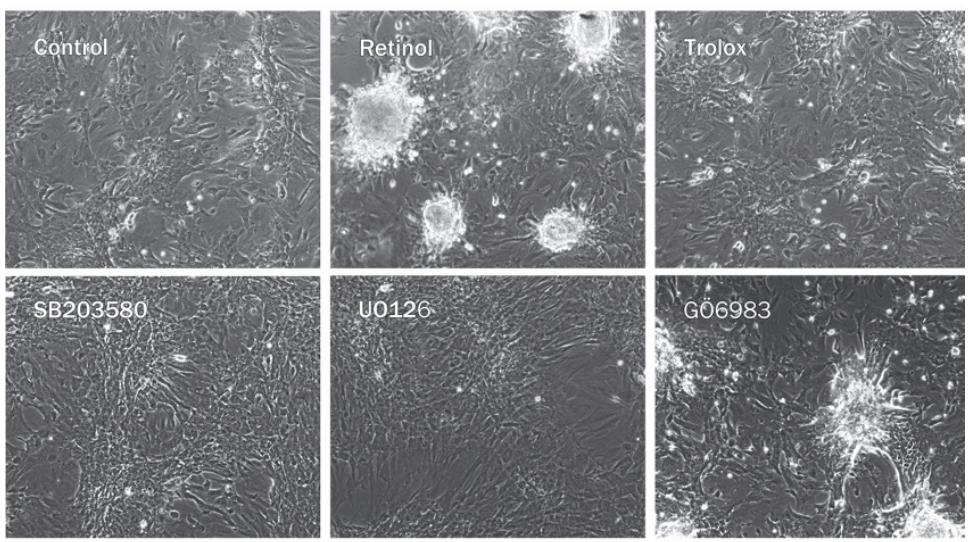

Figure 4. Proliferative focus morphology. Sertoli cells were treated for $24 \mathrm{~h}$ with retinol in the presence or absence of the antioxidant Trolox (100 $\mu \mathrm{mol} / \mathrm{L})$, the p38 inhibitor SB203580 (10 $\mathrm{mmol} / \mathrm{L})$, the JNK inhibitor SP600125 (10 $\mu \mathrm{mol} / \mathrm{L})$, the Akt inhibitor LY294002 $(10 \mu \mathrm{mol} / \mathrm{L})$, the ERK inhibitor U0126 $(10 \mu \mathrm{mol} / \mathrm{L})$ the pan-PKC inhibitor G0̈6983 (10 $\mu \mathrm{mol} / \mathrm{L})$ and the PKA inhibitor H89 (1
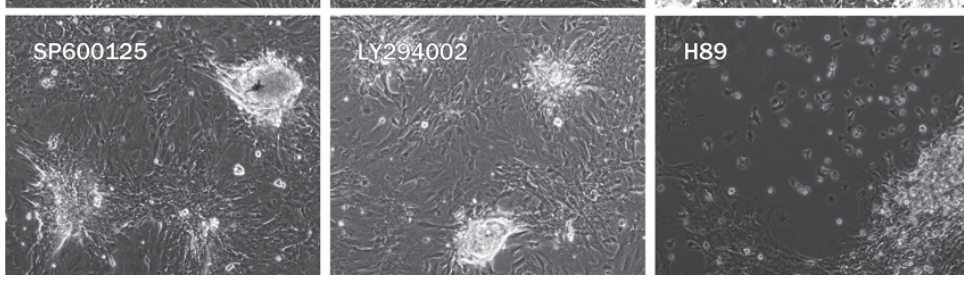
$\mu \mathrm{mol} / \mathrm{L}$ ); medium was then replaced in all groups for $10 \%$ FBSsupplemented 199 medium without any other compound for $14 \mathrm{~d}$, with exchange for fresh medium every $3 \mathrm{~d}$. At the end of the $14 \mathrm{~d}$ period, morphology was examined in a phase-contrast microscope (representative micrographs at $\times 40$ are depicted) and proliferative foci were counted in each well (see Figure $5 \mathrm{~A}$ for scores).
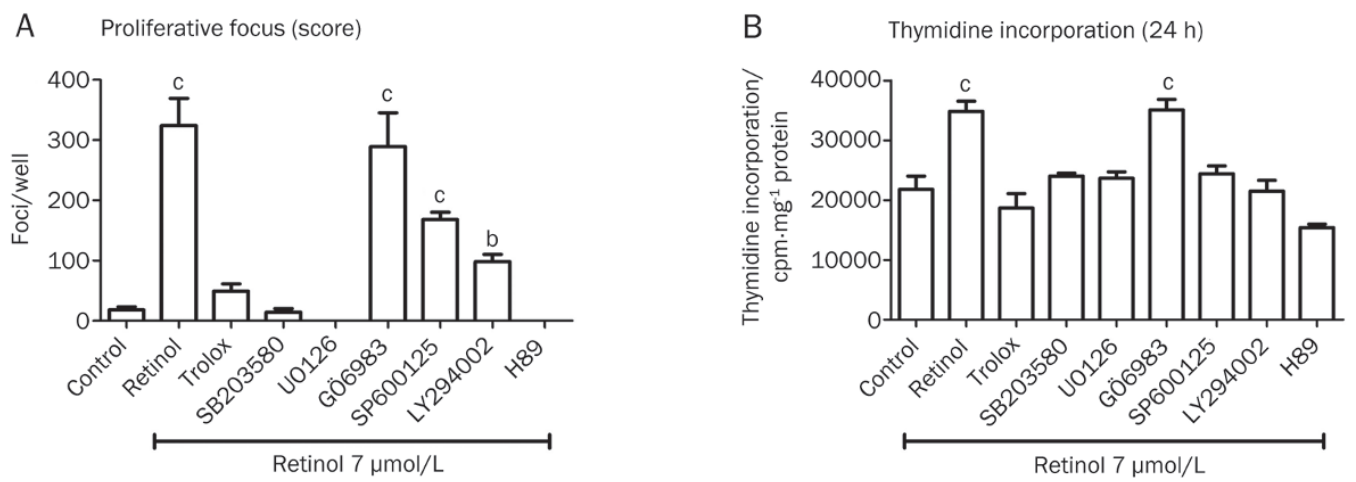

Figure 5. Proliferative focus scores and $\left[{ }^{3} \mathrm{H}\right] \mathrm{dT}$ incorporation in Sertoli cells. (A) Sertoli cells were treated for $24 \mathrm{~h}$ with retinol in the presence or

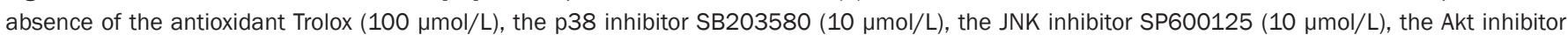

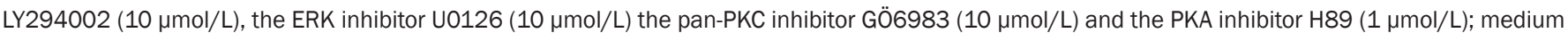
was then replaced in all groups for 10\% FBS-supplemented 199 medium without any other compound for 14 d, with exchange for fresh medium every $3 \mathrm{~d}$. At the end of the $14 \mathrm{~d}$ period, proliferative foci were counted in each well. (B) Sertoli cells were previously incubated with medium containing [ ${ }^{3} \mathrm{H}$ ] $\mathrm{dT}$, and then treated for $24 \mathrm{~h}$ in the same medium with retinol $7 \mu \mathrm{mol} / \mathrm{L}$ in the presence or absence of the above-mentioned compounds. Nuclei were isolated and incorporation of $\left[{ }^{3} \mathrm{H}\right] \mathrm{dT}$ was counted. Bars represent mean $\pm \mathrm{SEM}$ from three independent experiments (triplicate); data were analyzed by one-way ANOVA with Duncan's post hoc test. ${ }^{\mathrm{b}} \mathrm{P}<0.05,{ }^{\mathrm{c}} \mathrm{P}<0.01$ vs control.

free radical scavenging and control of cell cycle by retinoid receptor activity modulation ${ }^{[4]}$.

More recently, extensive clinical trials and experimental works evidenced a pro-neoplasic effect of retinol and derivatives ${ }^{[28-31]}$. Retinoids have been more properly considered "redox-active" molecules rather than solely antioxidants; its redox actions in biological systems are certainly dependent on a variety of factors, such as its intracellular concentration and interaction with other redox-active molecules ${ }^{[32]}$. Although a role for retinoid receptors may not be completely discharged in such malignant effect, there is strong evidence pointing to a more prominent role of free radicals and other nuclear receptor-independent pathways in the mechanism of neoplasic transformation by retinoids. Free radicals and related species have been extensively recognized as potential inducers of different types of cancer ${ }^{[33]}$, and MAPK-controlled signaling pathways and related proteins have been increasingly implicated in the control of cell cycle and triggering of oncogenic processes $^{[34]}$. Retinoids have been described to evoke both types of responses in Sertoli cells, a well-recognized physiological target of retinol and $\mathrm{RA}^{[35,36]}$.

We have previously demonstrated that concentrations above $5 \mu \mathrm{mol} / \mathrm{L}$ are able to induce deleterious effects on cells due to enhanced free radical production and oxidative dam- 
A Time course
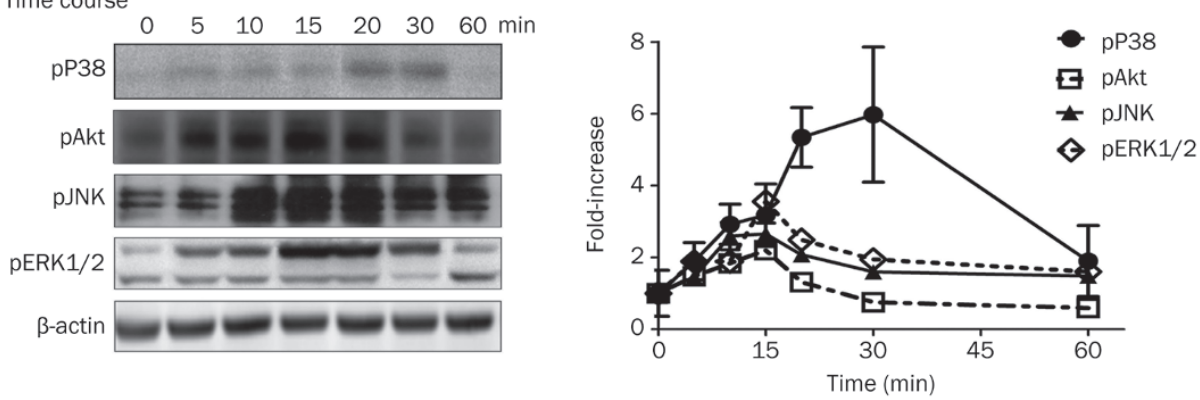
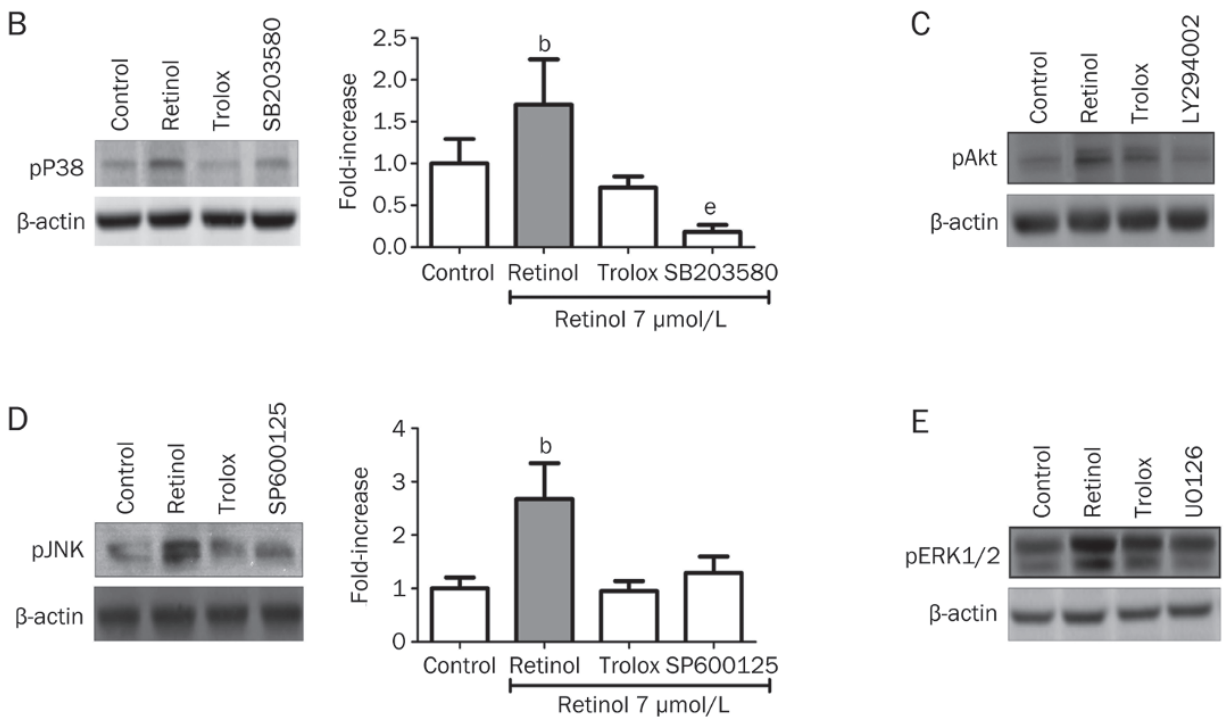

$\mathrm{E}$

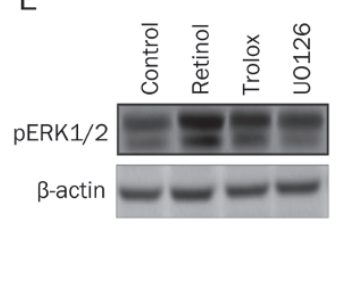

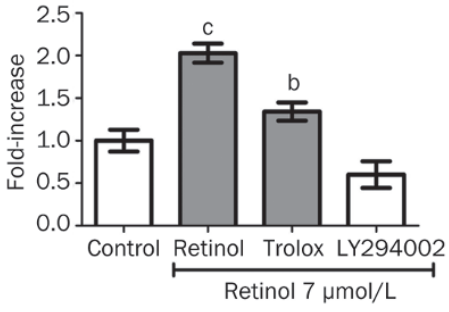

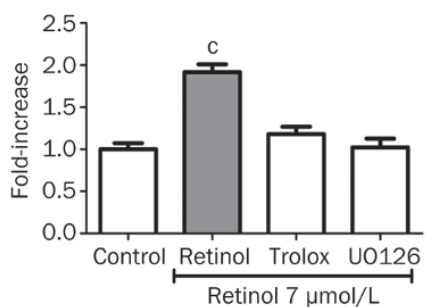

Figure 6. Representative immunoblots and quantification of levels of phosphorylated p38, Akt, JNK, and ERK1/2 in retinol-treated Sertoli cells. (A) Sertoli cells were treated with retinol $7 \mu \mathrm{mol} / \mathrm{L}$ and the time course of p38, Akt, JNK, and ERK1/2 during 60 min was evaluated by western blot using antibodies against phosphorylated forms of these protein kinases. Beta-actin was used as internal control. (B) The effect of the antioxidant Trolox $(100 \mu \mathrm{mol} / \mathrm{L})$ on $\mathrm{p} 38$ phosphorylation at $15 \mathrm{~min}$ of incubation with retinol was compared with the effect of the p38 inhibitor SB203580 (10 $\mu \mathrm{mol} / \mathrm{L})$. The effect of Trolox on Akt (C), JNK (D), and ERK1/2 (E) phosphorylation was also compared, respectively, with the effect of the inhibitors LY294002

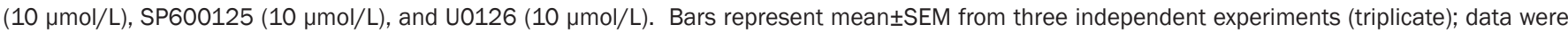
analyzed by one-way ANOVA with Duncan's post hoc test; asterisks denote significantly higher than control. ${ }^{\mathrm{b}} P<0.05,{ }^{\mathrm{C}} P<0.01$ vs control. ${ }^{\mathrm{e}} P<0.05$ vs Trolox.

age to biomolecules ${ }^{[17,19,21,31,37]}$. We also observed that retinol induces the rapid activation of phosphorylation-controlled signal pathways involving ERK1/2, JNK, and Src in a redoxdependent fashion, indicating the involvement of reactive species in the so-called non-genomic signaling by vitamin $\mathrm{A}^{[18,38]}$. Since kinase activation by retinol displays a peak of phosphorylation followed by a return to control levels within the period of 60 minutes, it seems that free radical production during the initial moments of retinol incubation are important for this effect. Normally, retinoid receptor activation in Sertoli cells is part of the paracrine signaling involved in the support and control of spermatogenesis, along with testosterone and Follicle-stimulating hormone (FSH).

Sertoli cells cease mitosis after birth and remain as fully differentiated and non-proliferative supportive cells. Physiological concentrations of retinoids do not affect the Sertoli cell cycle homeostasis in normal conditions ${ }^{[36]}$. However, pro- oxidant concentrations of retinol may induce proliferative effects related or not to malignancy, as free radicals are recognized to be involved in the regulation of cell cycle, especially in cell division and cell death ${ }^{[39]}$. Here, we observed that specific concentrations of retinol increase free radical production and parameters related to cell division and deformation. Cell cycle activation induced by pro-oxidant concentrations of retinol is probably related to cell transformation, since $\left[{ }^{3} \mathrm{H}\right] \mathrm{dT}$ incorporation was accompanied by proliferative focus formation and cell shape deformation, and these effects were reversed by antioxidant treatment. MAPK and Akt activation is also involved in the redox-dependent promotion of cell division by retinol, but not all these kinases are necessarily involved in cell transformation. Although the involvement of MAPKs in cell division control and transformation is well recognized, as mentioned earlier, different members of the MAPK family and related kinases may regulate different path- 
ways associated to activation of normal mitosis and malignant transformation in a given cell type, and this may vary under different conditions.

Many of the cell cycle regulatory effects promoted by different members of the MAPK family have also been observed to be evoked or strongly influenced by free radicals and related species. ERK was demonstrated to be involved in the free radical-mediated promotion of transformation or in the increase to transformation susceptibility ${ }^{[40,41]}$. The p38 MAPK was observed to be a key contributor for the redox signaling involved in UVA-mediated transformation ${ }^{[42]}$ and was postulated to exert a selective role in promoting free radicalmediated tumorigenesis ${ }^{[43]}$.

The extent of the role of cell phenotype in modulation of cell growth is a central question in the biomedical sciences ${ }^{[44]}$. In human non-small cell lung carcinoma cell lines, two- and three-dimensional growth patterns were described to follow a common growth dynamic associated to malignancy, such as in the case of the association with the Gompertz model for growing $^{[45,46]}$. It has been suggested that cell-shape compression control the inhibitory feedback as a geometrical arrest of mitosis, reflecting the influence of the cytoskeletal network organization $^{[47]}$. As cells become rounded, DNA synthesis gradually stops ${ }^{[48]}$; inversely, most cells require spreading on extracellular matrix substrate for proper growth and normal function ${ }^{[49]}$. Such relationships among growth and shape have been studied by regression analysis and resulted in a cell deformation parameter - the deformation coefficient $D$, which describes the amplitude of cell shape variation, showing positive correlation with kinetic parameters of growth described by the Gompertz model ${ }^{[24]}$.

Decrease in coefficient $D$ value is related to decreased cellto-cell recognition, adhesion and contact inhibition, and retinol treatment led to a decrease in this parameter. ERK1/2 and p38 inhibition reversed this effect, indicating that pathways controlled by these kinases are involved in the modulation of morphological parameters related to malignant transformation in these cells. Other kinase-controlled pathways such as the JNK and Akt seem to be involved in other effects promoted in a redox-dependent fashion by retinol in these cells; JNK inhibition blocked proliferative focus formation, while Akt inhibition hindered $\left[{ }^{3} \mathrm{H}\right] \mathrm{dT}$ incorporation, indicating a role in DNA synthesis. While inhibition of some kinases blocked or partially inhibited specific parameters related to proliferation or morphology change, our results indicate that ERK1/2 are involved in all aspects related to redox-dependent modifications on such parameters. ERK1/2 are highly sensitive to regulation by reactive species ${ }^{[50]}$, and previous works from our group indicated that these kinases are involved in the activation of matrix metalloproteinase- 2 by retinol in a redoxdependent fashion ${ }^{[51]}$.

It has been increasingly clear that the concentration of retinoids influences their actions on biological systems, and this seems to be related to changes in their redox profile. As a redox active molecule, retinol may take part in different oxidation-reduction cycles of several biomolecules and micronutrients that change their oxidation states according the redox conditions of their microenvironment ${ }^{[5]}$. It was observed both in cell cultures and animal models ${ }^{[10,52]}$ that retinol-induced oxidative stress is caused by the administration of concentrations above the reported physiological limit, which would increase the availability of this molecule to take part in oxidation-reduction cycles inside cells. On the other hand, it was recently reported that retinol is able to induce the mitochondrial activity by enhancing pyruvate dehydrogenase activity through a nongenomic mechanism of PKC activation, thus resulting in increased free radical formation ${ }^{[53]}$. This would explain why increased concentrations of retinol induce reactive species production in both cell cultures and animal models.

Concluding, reactive oxygen species production induced by retinol activates different protein kinase pathways, which we found to be related to different morphologic and proliferative alterations in Sertoli cells. Inhibition of p38, JNK, ERK1/2, Akt, and PKA decreased retinol-induced $\left[{ }^{3} \mathrm{H}\right] \mathrm{dT}$ incorporation; p38, ERK1/2, JNK, and Akt are also involved in retinolinduced proliferative focus formation. ERK1/2 and p38 inhibition reversed transformation-associated deformation, while other treatments did not show any effect. Co-treatment with the antioxidant Trolox inhibited phosphorylation of p38, ERK1/2, JNK, and Akt, indicating the activation of these kinases during retinol treatment is dependent on oxidative stress. These results indicate that consumption of vitamin A at high levels must be better evaluated at clinical and epidemiological levels, as concentrations of retinol slightly above cellular physiological levels induces the activation of several pathways associated to cell deformation and pre-neoplasic transformation, as observed here. Experimental therapies or supplementation protocols using vitamin A should be more extensively studied in regard to their safety, possible toxicological effects and long-term side-effects.

\section{Acknowledgements}

This work was financed by the Brazilian agencies CNPq (IBNNet \#01.06.0842-00 and 470234/2008), FAPERGS (PqG 6/20101008860 and 11/1893-7) and PROPESQ-UFRGS. The authors have no conflict of interest.

\section{Author contribution}

Daniel Pens GELAIN performed research, analyzed data and wrote the manuscript. José Claudio Fonseca MOREIRA supervised research and designed experiments. Matheus Augusto de Bittencourt PASQUALI, Fernanda Freitas CAREGNATO, and Mauro Antonio Alves CASTRO performed research.

\section{References}

1 Marletaz F, Holland LZ, Laudet V, Schubert M. Retinoic acid signaling and the evolution of chordates. Int J Biol Sci 2006; 2: 38-47.

2 Malaspina A, Turkheimer F. A review of the functional role and of the expression profile of retinoid signaling and of nuclear receptors in human spinal cord. Brain Res Bull 2007; 71: 437-46. 
3 Mongan NP, Gudas LJ. Diverse actions of retinoid receptors in cancer prevention and treatment. Differentiation 2007; 75: 853-70.

4 Fields AL, Soprano DR, Soprano KJ. Retinoids in biological control and cancer. J Cell Biochem 2007; 102: 886-98.

5 Halliwell B, Gutteridge JMC. Free radicals in biology and medicine. 4th ed. Oxford Oxford University Press; 2007.

6 Omenn GS, Goodman GE, Thornquist MD, Rosenstock L, Barnhart S, Gylys-Colwell l, et al. The Carotene and Retinol Efficacy Trial (CARET) to prevent lung cancer in high-risk populations: pilot study with asbestos-exposed workers. Cancer Epidemiol Biomarkers Prev 1993; 2: 381-7.

7 Omenn GS, Goodman GE, Thornquist MD, Balmes J, Cullen MR, Glass $A$, et al. Effects of a combination of beta carotene and vitamin $A$ on lung cancer and cardiovascular disease. N Engl J Med 1996; 334: 1150-5.

8 Murata M, Kawanishi S. Oxidative DNA damage by vitamin A and its derivative via superoxide generation. J Biol Chem 2000; 275: 20038.

9 Pasquali MA, Schnorr CE, Feistauer LB, Gelain DP, Moreira JC. Vitamin A supplementation to pregnant and breast feeding female rats induces oxidative stress in the neonatal lung. Reprod Toxicol 2010; 30: 452-6.

10 Pasquali MA, Gelain DP, de Oliveira MR, Behr GA, da Motta LL, da Rocha RF, et al. Vitamin A supplementation for different periods alters oxidative parameters in lungs of rats. J Med Food 2009; 12: 1375-80.

11 Masia S, Alvarez S, de Lera AR, Barettino D. Rapid, nongenomic actions of retinoic acid on phosphatidylinositol-3-kinase signaling pathway mediated by the retinoic acid receptor. Mol Endocrinol 2007; 21: 2391-402.

12 Canon E, Cosgaya JM, Scsucova S, Aranda A. Rapid effects of retinoic acid on CREB and ERK phosphorylation in neuronal cells. Mol Biol Cell 2004; 15: 5583-92.

13 Liou JC, Ho SY, Shen MR, Liao YP, Chiu WT, Kang KH. A rapid, nongenomic pathway facilitates the synaptic transmission induced by retinoic acid at the developing synapse. J Cell Sci 2005; 118: 472130.

14 Liao YP, Ho SY, Liou JC. Non-genomic regulation of transmitter release by retinoic acid at developing motoneurons in Xenopus cell culture. J Cell Sci 2004; 117: 2917-24.

15 Gelain DP, Moreira JC, Bevilaqua LR, Dickson PW, Dunkley PR. Retinol activates tyrosine hydroxylase acutely by increasing the phosphorylation of serine 40 and then serine 31 in bovine adrenal chromaffin cells. J Neurochem 2007; 103: 2369-79.

16 Gelain DP, de Bittencourt Pasquali MA, Zanotto-Filho A, de Souza LF, de Oliveira RB, Klamt F, et al. Retinol increases catalase activity and protein content by a reactive species-dependent mechanism in Sertoli cells. Chem Biol Interact 2008; 174: 38-43.

17 Gelain DP, de Bittencourt Pasquali MA, Caregnato FF, Zanotto-Filho A, Moreira JC. Retinol up-regulates the receptor for advanced glycation end products (RAGE) by increasing intracellular reactive species. Toxicol In Vitro 2008; 22: 1123-7.

18 Gelain DP, Cammarota M, Zanotto-Filho A, de Oliveira RB, DalPizzol F, Izquierdo I, et al. Retinol induces the ERK1/2-dependent phosphorylation of CREB through a pathway involving the generation of reactive oxygen species in cultured Sertoli cells. Cell Signal 2006; 18: $1685-94$.

19 Dal-Pizzol F, Klamt F, Frota ML Jr, Moraes LF, Moreira JC, Benfato MS. Retinol supplementation induces DNA damage and modulates iron turnover in rat Sertoli cells. Free Radic Res 2000; 33: 677-87.

20 Dal-Pizzol F, Klamt F, Dalmolin RJ, Bernard EA, Moreira JC. Mitogenic signaling mediated by oxidants in retinol treated Sertoli cells. Free Radic Res 2001; 35: 749-55.

21 Dal-Pizzol F, Klamt F, Benfato MS, Bernard EA, Moreira JC. Retinol supplementation induces oxidative stress and modulates antioxidant enzyme activities in rat sertoli cells. Free Radic Res 2001; 34: 395404.

22 Draper $\mathrm{HH}$, Hadley M. Malondialdehyde determination as index of lipid peroxidation. Methods Enzymol 1990; 186: 421-31.

23 Levine RL, Garland D, Oliver CN, Amici A, Climent I, Lenz AG, et al. Determination of carbonyl content in oxidatively modified proteins. Methods Enzymol 1990; 186: 464-78.

24 Castro MA, Klamt F, Grieneisen VA, Grivicich I, Moreira JC. Gompertzian growth pattern correlated with phenotypic organization of colon carcinoma, malignant glioma and non-small cell lung carcinoma cell lines. Cell Prolif 2003; 36: 65-73.

25 Ross AC, Zolfaghari R, Weisz J. Vitamin A: recent advances in the biotransformation, transport, and metabolism of retinoids. Curr Opin Gastroenterol 2001; 17: 184-92.

26 de Oliveira RB, Klamt F, Castro MA, Polydoro M, Zanotto Filho A, Gelain DP, et al. Morphological and oxidative alterations on Sertoli cells cytoskeleton due to retinol-induced reactive oxygen species. Mol Cell Biochem 2005; 271: 189-96.

27 Gelain DP, de Bittencourt Pasquali MA, Caregnato FF, Moreira JC. Vitamin A (retinol) up-regulates the receptor for advanced glycation end products (RAGE) through p38 and Akt oxidant-dependent activation. Toxicology 2011; 289: 38-44.

28 Kim J, Kim MK, Lee JK, Kim JH, Son SK, Song ES, et al. Intakes of vitamin $A, C$, and $E$, and beta-carotene are associated with risk of cervical cancer: a case-control study in Korea. Nutr Cancer 2010; 62: 181-9.

29 The ABC-Cancer Prevention Study Group. The effect of vitamin E and beta carotene on the incidence of lung cancer and other cancers in male smokers. The Alpha-Tocopherol, Beta Carotene Cancer Prevention Study Group. N Engl J Med 1994; 330: 1029-35.

30 Omenn GS, Goodman G, Thornquist M, Grizzle J, Rosenstock L, Barnhart S, et al. The beta-carotene and retinol efficacy trial (CARET) for chemoprevention of lung cancer in high risk populations: smokers and asbestos-exposed workers. Cancer Res 1994; 54: 2038s-43s.

31 Klamt F, Dal-Pizzol F, Roehrs R, de Oliveira RB, Dalmolin R, Henriques $\mathrm{JA}$, et al. Genotoxicity, recombinogenicity and cellular preneoplasic transformation induced by vitamin A supplementation. Mutat Res 2003; 539: 117-25.

32 Krinsky NI, Johnson EJ. Carotenoid actions and their relation to health and disease. Mol Aspects Med 2005; 26: 459-516.

33 Oyagbemi AA, Azeez OI, Saba AB. Interactions between reactive oxygen species and cancer: the roles of natural dietary antioxidants and their molecular mechanisms of action. Asian Pac J Cancer Prev 2009; 10: 535-44.

34 Haagenson KK, Wu GS. The role of MAP kinases and MAP kinase phosphatase-1 in resistance to breast cancer treatment. Cancer Metastasis Rev 2010; 29: 143-9.

35 Silva FR, Leite LD, Wassermann GF. Rapid signal transduction in Sertoli cells. Eur J Endocrinol 2002; 147: 425-33.

36 Hogarth CA, Griswold MD. The key role of vitamin A in spermatogenesis. J Clin Invest 2010; 120: 956-62.

37 de Oliveira RB, de Bittencourt Pasquali MA, Filho AZ, Dalmolin RJ, Gelain DP, Gottfried C, et al. Can electrons travel through actin microfilaments and generate oxidative stress in retinol treated Sertoli cell? Mol Cell Biochem 2007; 301: 33-45.

38 Zanotto-Filho A, Gelain DP, Schroder R, Souza LF, Pasquali MA, Klamt F, et al. The NF kappa B-mediated control of RS and JNK signaling in 
vitamin A-treated cells: duration of JNK-AP-1 pathway activation may determine cell death or proliferation. Biochem Pharmacol 2009; 77: 1291-301.

39 Burhans WC, Heintz NH. The cell cycle is a redox cycle: linking phasespecific targets to cell fate. Free Radic Biol Med 2009; 47: 1282-93.

40 Hsu TC, Young MR, Cmarik J, Colburn NH. Activator protein 1 (AP-1)and nuclear factor kappaB (NF-kappaB)-dependent transcriptional events in carcinogenesis. Free Radic Biol Med 2000; 28: 1338-48.

41 Yang S, Misner B, Chiu R, Meyskens FL Jr. Common and distinct mechanisms of different redox-active carcinogens involved in the transformation of mouse JB6P+ cells. Mol Carcinog 2008; 47: 48591.

42 Cooper KL, Liu KJ, Hudson LG. Enhanced ROS production and redox signaling with combined arsenite and UVA exposure: contribution of NADPH oxidase. Free Radic Biol Med 2009; 47: 381-8.

43 Kennedy NJ, Cellurale C, Davis RJ. A radical role for p38 MAPK in tumor initiation. Cancer Cell 2007; 11: 101-3.

44 Chen Z, Smith CW, Kiel D, Van Waes C. Metastatic variants derived following in vivo tumor progression of an in vitro transformed squamous cell carcinoma line acquire a differential growth advantage requiring tumor-host interaction. Clin Exp Metastasis 1997; 15: 527 37.

45 Castro MA, Schwartsmann G, Bernard EA, Moreira JC. Phenotype modulation of cellular UV-sensitivity. Cancer Lett 1999; 145: 65-72.

46 Castro MA, Schwartsmann G, Moreira JC. Intercellular contact- dependent survival of human A549, NCl-H596 and $\mathrm{NCl}-\mathrm{H} 520$ nonsmall cell lung carcinoma cell lines. Braz J Med Biol Res 2001; 34: 1007-13.

47 Olive PL, Durand RE. Drug and radiation resistance in spheroids: cell contact and kinetics. Cancer Metastasis Rev 1994; 13: 121-38.

48 Chen CS, Mrksich M, Huang S, Whitesides GM, Ingber DE. Geometric control of cell life and death. Science 1997; 276: 1425-8.

49 Ruoslahti E, Vaheri A. Cell-to-cell contact and extracellular matrix. Curr Opin Cell Biol 1997; 9: 605-7.

50 McCubrey JA, Lahair MM, Franklin RA. Reactive oxygen speciesinduced activation of the MAP kinase signaling pathways. Antioxid Redox Signal 2006; 8: 1775-89.

51 Dalmolin RJ, Zanotto-Filho A, De Oliveira RB, Duarte RF, Pasquali MA, Moreira JC. Retinol and retinoic acid increase MMP-2 activity by different pathways in cultured Sertoli cells. Free Radic Res 2007; 41: 1338-47.

52 Pasquali MA, Gelain DP, Oliveira MR, Behr GA, Motta LL, Rocha $\mathrm{RF}$, et al. Vitamin A supplementation induces oxidative stress and decreases the immunocontent of catalase and superoxide dismutase in rat lungs. Exp Lung Res 2009; 35: 427-38.

53 Acin-Perez R, Hoyos B, Zhao F, Vinogradov V, Fischman DA, Harris RA, et al. Control of oxidative phosphorylation by vitamin A illuminates a fundamental role in mitochondrial energy homoeostasis. FASEB J 2010; 24: 627-36. 